\title{
Review
}

\section{Reductive dechlorination in the energy metabolism of anaerobic bacteria}

\author{
Christof Holliger ${ }^{\mathrm{a}}$, Gert Wohlfarth ${ }^{\mathrm{b}}$, Gabriele Diekert ${ }^{\mathrm{b}, *}$ \\ a Swiss Federal Institute for Environmental Science and Technology (EAWAG), Limnological Research Center, CH-6047 Kastanienbaum, \\ Switzerland \\ ${ }^{\mathrm{b}}$ University of Stuttgart, Institute for Microbiology, Allmandring 31, D-70569 Stuttgart, Germany
}

Received 12 July 1998; received in revised form 22 September 1998; accepted 1 October 1998

\begin{abstract}
Within the last few decades, several anaerobic bacteria have been isolated which are able to reductively dechlorinate chlorinated aliphatic and aromatic compounds at catabolic rates. For some of these bacteria, it has been shown that the reductive dechlorination is coupled to energy conservation, a process designated as 'dehalorespiration'. Somewhat simple respiratory chains seem to be involved that utilize the free energy that could be gained from the exergonic dechlorination reaction quite inefficiently. With one exception, all reductive dehalogenases isolated to date contain a corrinoid and iron-sulfur clusters as cofactors. During the course of the catalytic reaction cycle, the cobalt of the corrinoid is subjected to a change in its redox state. Hence, reductive dechlorination represents a new type of biochemical reaction. (c) 1999 Federation of European Microbiological Societies. Published by Elsevier Science B.V. All rights reserved.
\end{abstract}

Keywords: Reductive dehalogenation; Dehalorespiration; Chlorophenol; Tetrachloroethene; Corrinoid; Vitamin $\mathrm{B}_{12}$

\section{Contents}

1. Introduction $\ldots \ldots \ldots \ldots \ldots \ldots \ldots \ldots \ldots$

2. Anaerobic bacteria capable of reductive dechlorination in their energy metabolism $\ldots \ldots \ldots 385$

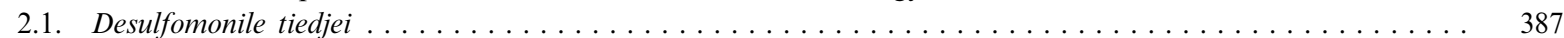

2.2. Isolate $2 \mathrm{CP}-1 \ldots \ldots \ldots \ldots \ldots \ldots$

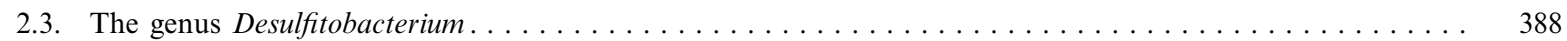

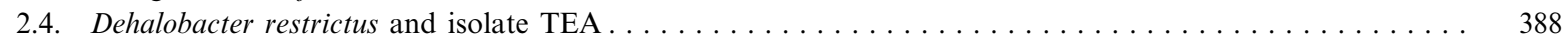

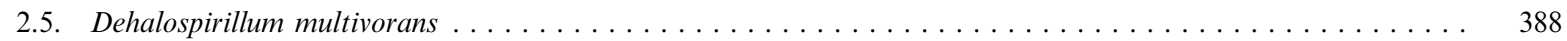

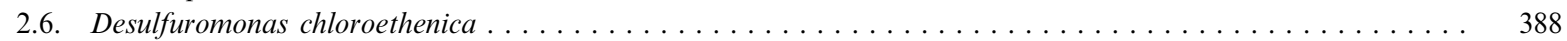

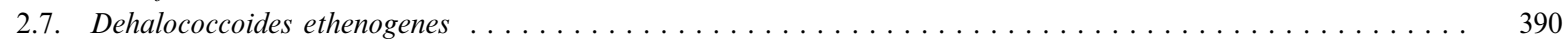

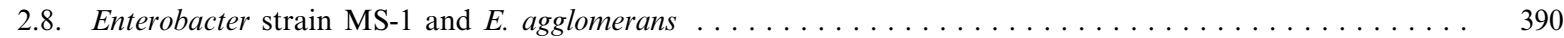

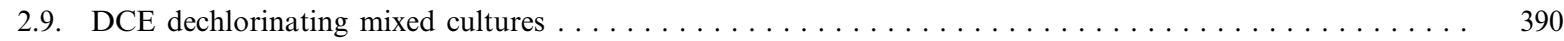

2.10. Reductive dechlorination in syntrophic associations $\ldots \ldots \ldots \ldots \ldots$

3. Biochemistry and molecular biology of reductive dehalogenases $\ldots \ldots \ldots 390$

* Corresponding author. Tel.: +49 (711) 685-5483; Fax: +49 (711) 685-5725; E-mail: imbgd@po.uni-stuttgart.de 
3.1. 3-Chlorobenzoate reductive dehalogenase of Desulfomonile tiedjei . . . . . . . . . . . . . . . .

3.2. Ortho-chlorophenol reductive dehalogenases of Desulfitobacteria $\ldots \ldots \ldots \ldots \ldots$

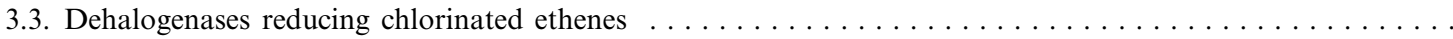

4. Reaction mechanism of corrinoid-dependent reductive dehalogenases $\ldots \ldots \ldots \ldots \ldots$

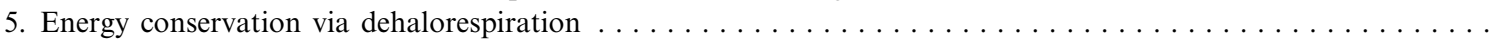

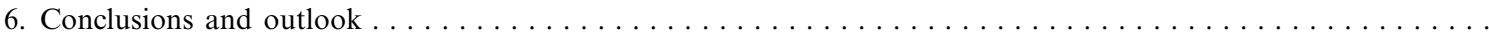

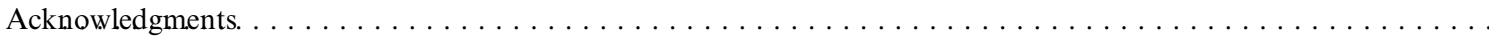

\section{Introduction}

Over the last few decades, several bacterial cultures, both mixed and pure, have been described which are capable of reductive dechlorination of chlorinated aliphatic and aromatic hydrocarbons. These chlorinated hydrocarbons include compounds frequently encountered as environmental contaminants known to be hazardous and toxic for animals and plants, or destructive to the ozone layer. Although numerous reports and reviews on microbial reductive dechlorination activities are available [1-9], this process is not, as yet, completely understood. Many of the studies involved co-metabolic or abiotic reductive dechlorination, or dechlorination by mixed cultures, facultative anaerobes or aerobic bacteria, which will not be discussed in this communication. Nevertheless, it should be noted that several aerobes can catalyze reductive dechlorination reactions. In some aerobes, this reaction appeared to be dependent on glutathione [10], whereas in others, a requirement for NADH as an electron donor was observed [11]. The compounds reductively dechlorinated by these organisms were usually intermediates formed during the aerobic degradation of chlorinated aromatics.

Reductive dechlorination under strictly anoxic conditions was observed for a variety of anaerobes, including methanogenic and homoacetogenic bacteria $[1,2,7]$. In most cases, the process appeared to be mediated in cell-free systems by heat-stable compounds at low velocities. Due to the dechlorinating activity of tetrapyrrole-cofactors, such as corrinoids, iron porphyrins, and coenzyme $\mathrm{F}_{430}$ in aqueous solution [3], it has been proposed that in many dechlorinating bacteria the dechlorination reaction is a co-metabolic activity of enzymes containing these cofactors as prosthetic groups. For some co-meta- bolically dechlorinating bacteria, it has been demonstrated that tetrapyrrol-containing enzymes are indeed responsible for the dechlorination reaction they catalyze. This type of reductive dechlorination reaction is extensively described in [1] and will not be discussed in this review.

In this communication, the description of the reductive dechlorination process in pure cultures and with purified enzymes will emphasize those bacteria which utilize the energy generated in the dechlorination process for the synthesis of ATP. This respiratory process is referred to as 'dehalorespiration' throughout the entire communication. In other reports, the terms 'halorespiration' or 'chlororespiration', which suggest that a halogen serves as terminal electron acceptor (in analogy to e.g. fumarate or nitrate respiration), have been used. Since this is not the case, the term 'dehalorespiration' is preferable, as it indicates that the dehalogenation process is coupled to ATP synthesis via a chemiosmotic mechanism. A prerequisite for the coupling of an energy conservation to reductive dechlorination is that the reaction:

$\mathrm{R}-\mathrm{Cl}+2[\mathrm{H}] \rightarrow \mathrm{R}-\mathrm{H}+\mathrm{H}^{+}+\mathrm{Cl}^{-}$

is thermodynamically favorable.

It has been demonstrated that this reaction is usually exergonic, as shown for tetrachloroethene or 3-chlorobenzoate in Fig. 1. For most halogenated compounds, the standard redox potential for the couplet R-Cl/R-H lies between approximately +250 and $+600 \mathrm{mV}[8,12]$. Therefore, these compounds are thermodynamically favorable as electron acceptors under anaerobic conditions. This is also true of monohalogenated compounds, some of which, for example vinyl chloride and monochlorobenzene, are often dechlorinated slowly, if at all. Anaerobes capa- 

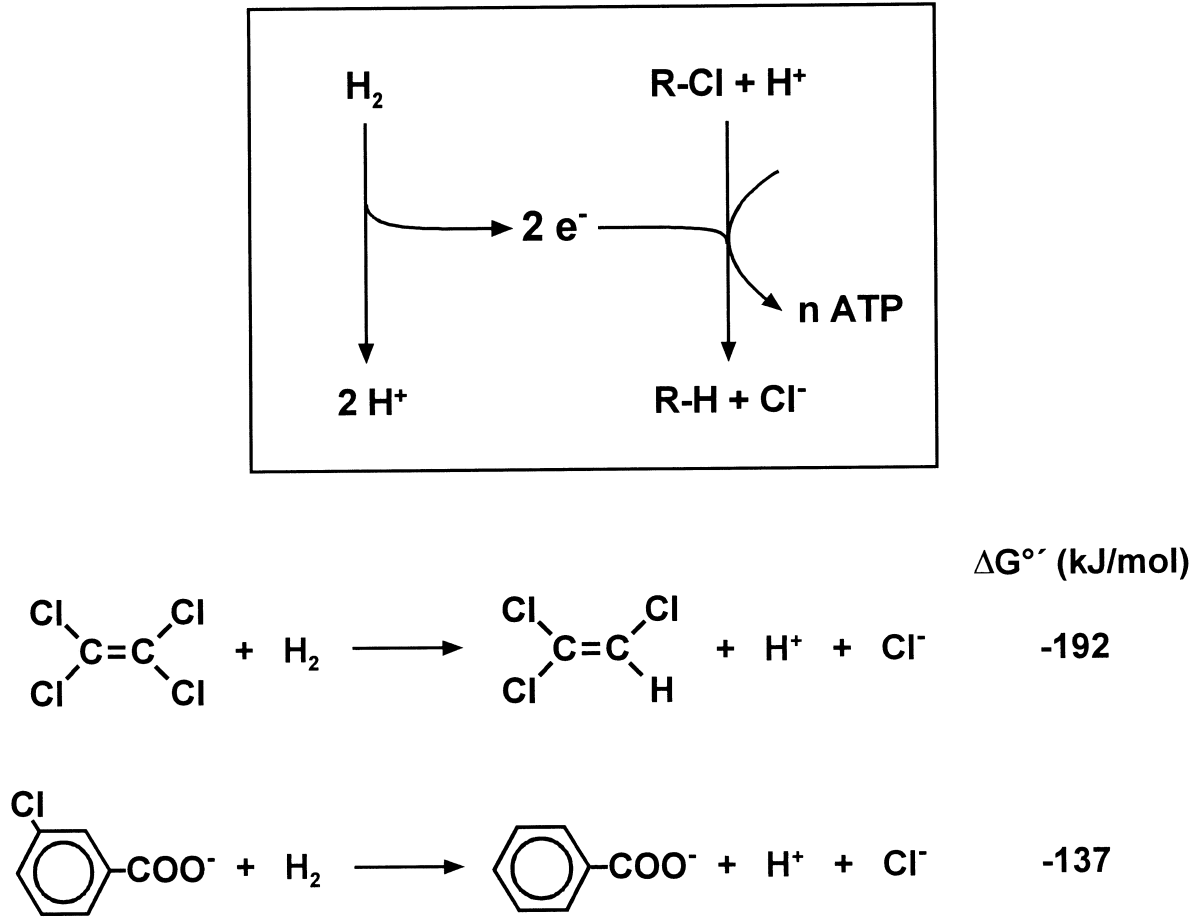

Fig. 1. Scheme of dehalorespiration with $\mathrm{H}_{2}$ as electron donor and tetrachloroethene or 3-chlorobenzoate as electron acceptor.

ble of growth on a defined medium with the chlorinated substrate as the electron acceptor and an electron donor like $\mathrm{H}_{2}$ or formate, the oxidation of which cannot be coupled to the synthesis of ATP (Fig. 1), have to gain their energy from dehalorespiration. For those organisms which require an electron donor yielding ATP via substrate level phosphorylation during oxidation, dehalorespiration is difficult to prove unambiguously, even if the organism depends on the presence of the chlorinated compound as an electron acceptor. It is feasible that the organohalogen merely serves as a favorable and/or necessary electron sink for reducing equivalents generated upon oxidation of the electron donor.

\section{Anaerobic bacteria capable of reductive dechlorination in their energy metabolism}

Chlorinated substrates reported to be reductively dehalogenated by pure cultures of anaerobes in their energy metabolism fall into two categories: chlori- nated aromatic compounds, such as chlorinated benzoate or phenols, on the one hand and chlorinated ethenes on the other. Other organochlorines, such as polychlorinated biphenyls and chlorinated benzenes, also appear to be reductively dechlorinated in similar physiological processes $[1,2,7]$. Since little is known about the bacteria involved, this process will not be further discussed.

Aryl halides are converted by Desulfomonile tiedjei and the facultative anaerobe isolate $2 \mathrm{CP}-1$, as well as by members of the newly described genus, Desulfitobacterium. Some species of the latter genus are also able to reduce tetrachloroethene (PCE) and trichloroethene (TCE). Other PCE reducing organisms include Dehalobacter restrictus and the closely related isolate TEA, as well as Dehalospirillum multivorans, Desulfuromonas chloroethenica, Dehalococcoides ethenogenes, and the facultative anaerobes Enterobacter strain MS-1 and Enterobacter agglomerans. All of the microorganisms capable of reductive dechlorination belong to the bacteria, several of them being related to sulfate or sulfur reducers in the $\delta$ - and $\varepsilon$-sub- 


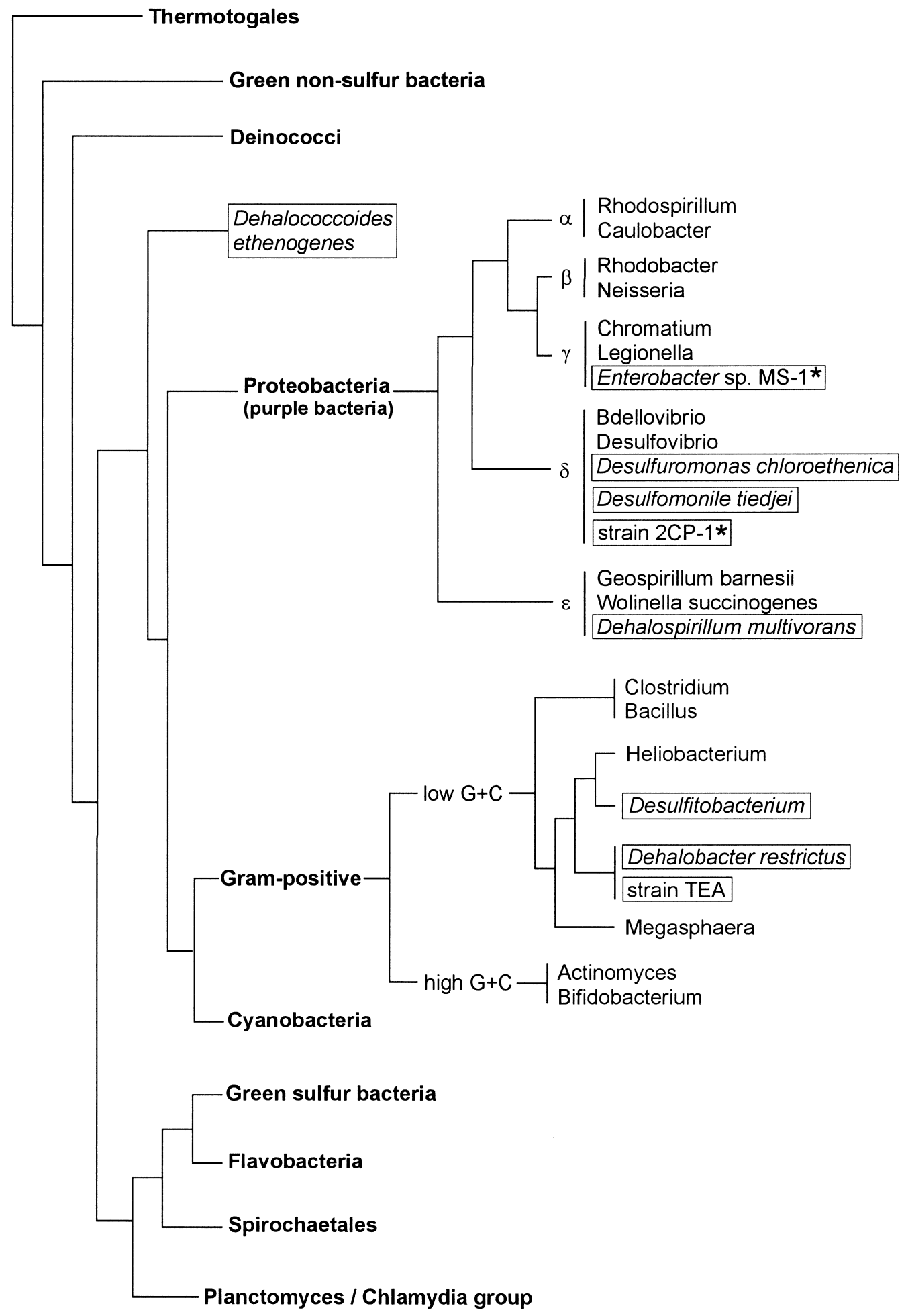

Fig. 2. Phylogenetic affiliations, based on analysis of $16 \mathrm{~S}$ ribosomal RNA gene sequences, of bacteria capable of reductive dechlorination (framed). The facultative anaerobes are marked with an asterisk. 
Table 1

Anaerobic bacteria capable of reductive dechlorination in the catabolism

\begin{tabular}{|c|c|c|c|}
\hline & Dechlorinated compounds ${ }^{\mathrm{a}}$ & Electron donor ${ }^{\mathrm{a}}$ & Remarks \\
\hline Desulfomonile tiedjei [14] & $\begin{array}{l}\text { PCE, } \mathrm{TCEH}_{2}, 3 \text {-chlorobenzoate, } \\
\text { pentachlorophenol }\end{array}$ & $\begin{array}{l}\mathrm{H}_{2} \text {, formate, } \\
\text { pyruvate }\end{array}$ & meta dechlorination \\
\hline Isolate $2 \mathrm{CP}-1$ [22] & 2-chlorophenol, 2,6-dichlorophenol & acetate & $\begin{array}{l}\text { facultative anaerobe; } \\
\text { ortho dechlorination }\end{array}$ \\
\hline $\begin{array}{l}\text { Desulfitobacterium chlororespirans } \\
\text { [26] }\end{array}$ & 2,4,6-trichlorophenol, 3-Cl-4-OH-phenylacetate & $\begin{array}{l}\mathrm{H}_{2}, \text { formate, } \\
\text { pyruvate }\end{array}$ & ortho dechlorination \\
\hline Desulfitobacterium hafniense [24] & 3-Cl-4-OH-phenylacetate, pentachlorophenol & $\begin{array}{l}\text { pyruvate, } \\
\text { tryptophan }\end{array}$ & ortho, meta dechlorination \\
\hline Desulfitobacterium frappieri [27] & 2,4,6-trichlorophenol, 3-Cl-4-OH-phenylacetate & pyruvate & $\begin{array}{l}\text { ortho, meta, para } \\
\text { dechlorination }\end{array}$ \\
\hline $\begin{array}{l}\text { Desulfitobacterium dehalogenans } \\
\text { [28] }\end{array}$ & $\begin{array}{l}\text { PCE, 2,4,6-trichlorophenol, } \\
\text { 3-Cl-4-OH-phenylacetate }\end{array}$ & $\begin{array}{l}\mathrm{H}_{2} \text {, formate, } \\
\text { pyruvate }\end{array}$ & ortho dechlorination \\
\hline $\begin{array}{l}\text { Desulfitobacterium strain } \\
\text { PCE1 [25] }\end{array}$ & $\begin{array}{l}\text { PCE, 2-chlorophenol, 2,4,6-trichlorophenol, } \\
\text { 3-Cl-4-OH-phenylacetate }\end{array}$ & formate, pyruvate & $\begin{array}{l}\text { minor TCE reduction; } \\
\text { ortho dechlorination }\end{array}$ \\
\hline $\begin{array}{l}\text { Desulfitobacterium strain } \\
\text { PCE-S [23] }\end{array}$ & $\begin{array}{l}\text { PCE, TCE, 2,4,5-trichlorophenol, } \\
\text { pentachlorophenol }\end{array}$ & pyruvate & ortho, meta dechlorination \\
\hline Dehalobacter restrictus [32] & PCE, TCE & $\mathrm{H}_{2}$ & \\
\hline Isolate TEA [33] & PCE, TCE & $\mathrm{H}_{2}$ & \\
\hline Dehalospirillum multivorans [35] & PCE, TCE & $\begin{array}{l}\mathrm{H}_{2} \text {, formate, } \\
\text { pyruvate }\end{array}$ & \\
\hline Desulfuromonas chloroethenica [39] & PCE, TCE & pyruvate, acetate & \\
\hline $\begin{array}{l}\text { Dehalococcoides ethenogenes } \\
\text { strain } 195 \text { [42] }\end{array}$ & PCE, TCE, DCE, chloroethene & $\mathrm{H}_{2}$ & \\
\hline Enterobacter strain MS-1 [43] & PCE, TCE & $\begin{array}{l}\text { formate, pyruvate, } \\
\text { acetate }\end{array}$ & facultative anaerobe \\
\hline
\end{tabular}

PCE, tetrachloroethene; TCE, trichloroethene.

${ }^{a}$ Incomplete selection.

groups of the proteobacteria. The phylogenetic position of the bacteria capable of reductive dechlorination is depicted in Fig. 2. Table 1 summarizes some characteristics of these organisms, especially with respect to the reductive dechlorination process.

\subsection{Desulfomonile tiedjei}

This microorganism is a Gram-negative sulfate-reducing bacterium belonging to the $\delta$-subgroup of the Proteobacteria $[13,14]$. The bacterium contains cytochrome $c$ and is dependent on 1,4-naphthoquinone as a growth factor [7]. It is able to grow with hydrogen as an electron donor and 3-chlorobenzoate as an electron acceptor [15]. Energy conservation via dehalorespiration was unambiguously demonstrated for the first time in this organism [16,17]. Cell suspensions and cell extracts were also shown to reductively dechlorinate PCE to cis-1,2-dichloroethene (DCE). Evidence is available that 3-chlorobenzoate and
PCE are converted by the same enzyme, as indicated by co-induction with 3-chlorobenzoate [18], and by the similar inhibition patterns of both reductive dechlorination activities [19]. The enzyme is not inducible by PCE, indicating that PCE reduction is probably a side reaction of chlorobenzoate reductive dehalogenase. Upon induction of the enzyme by 3 -chlorobenzoate, the synthesis of an unusual cytochrome $c$ with a negative standard redox potential of $-342 \mathrm{mV}$ was co-induced [20]. Sulfite and thiosulfate, rather than sulfate, inhibited reductive dechlorination in crude extracts, whereas sulfate repressed the reductive dehalogenase [21]. The 3 -chlorobenzoate reductive dehalogenase has been purified and partially characterized (Table 2).

\subsection{Isolate $2 C P-1$}

This facultative anaerobe belongs to the same subgroup as $D$. tiedjei. It is, however, more closely re- 
lated to the fruiting myxobacteria, which are obligate aerobes. Strain 2CP-1 reductively dechlorinates 2chlorophenol with acetate as electron donor [22]. 2Chlorophenol is only converted under strictly anoxic conditions.

\subsection{The genus Desulfitobacterium}

Desulfitobacterium is a newly described genus of Gram-positive bacteria. Some species are able to form endospores. In some of the organisms, menaquinone [23], cytochrome $b$ [23], and cytochrome $c$ [23-25] have been detected. Desulfitobacterium species are capable of reductive dehalogenation of a variety of chlorinated compounds. Alternatively, members of this genus, with one exception (see below), can utilize sulfite and thiosulfate, but not sulfate, as terminal electron acceptors. For most Desulfitobacteria described, dehalorespiration appears doubtful or is insufficiently documented, if documented at all. Most of the organisms utilize electron donors, such as pyruvate or grow in complex, undefined media. The reductive dehalogenases for the conversion of the aryl halides appear to be inducible, whereas the PCE reductive dehalogenases are either constitutively expressed or their inducibility not yet studied. Desulfitobacterium chlororespirans [26], Desulfitobacterium hafniense [24], and Desulfitobacterium frappieri [27] reduce chlorinated phenols, such as 2,4,6-trichlorophenol or 3-chloro-4-hydroxy-phenylacetate (Cl-OHPA). The Cl-OHPA reductive dehalogenase has been purified from Desulfitobacterium hafniense and Desulfitobacterium dehalogenans (Table 2).

Desulfitobacterium dehalogenans [25,28-30], Desulfitobacterium strain PCE1 [25], and Desulfitobacterium strain PCE-S [23] are able to convert chlorinated phenols as well as PCE. In contrast to the alkyl and aryl halide conversion carried out by $D e-$ sulfomonile tiedjei, these processes are mediated by different enzymes with respect to their substrate spectrum (see below). PCE is converted to TCE by $D e$ sulfitobacterium dehalogenans, whereas traces of DCE are formed by strain PCE1. The PCE reductive dehalogenase of strain PCE-S has been purified, and shown to mediate the reduction of PCE via TCE to DCE as the end product (Table 2). The latter organism is the only Desulfitobacterium which is not able to reduce sulfite or thiosulfate in its energy metabolism.

\subsection{Dehalobacter restrictus and isolate TEA}

Dehalobacter restrictus [31,32] and isolate TEA [33] are, based on 16S rDNA analysis, affiliated with the same group of Gram-positive bacteria as Desulfitobacterium. Dehalobacter restrictus contains menaquinones and cytochrome $b$. Dehalobacter restrictus, as well as isolate TEA, seem to be restricted to utilization of hydrogen as their electron donor and PCE or TCE as electron acceptors. Hence, these organisms derive metabolic energy from dehalorespiration [34]. The PCE reductive dehalogenase has been purified from Dehalobacter restrictus (Table 2 ), and has been found to reduce PCE to DCE.

\subsection{Dehalospirillum multivorans}

Dehalospirillum multivorans [35] is a Gram-negative bacterium belonging to the $\varepsilon$-subgroup of the Proteobacteria. It is very closely related to Geospirillum barnesii, although the latter organism is not able to dechlorinate PCE (Windfuhr, Scholz-Muramatsu and Diekert, unpublished). The organism contains menaquinone and cytochromes $b$ and $c$. Compared with Dehalobacter restrictus and strain TEA, Dehalospirillum multivorans is rather more versatile with respect to its substrate spectrum. Although it is able to grow with $\mathrm{H}_{2}$ and PCE as energy sources, indicating energy conservation via dehalorespiration, it is also able to utilize other electron donors, like pyruvate and formate, and alternative electron acceptors, e.g. fumarate, arsenate, and selenate. Some of these alternative electron acceptors have been shown to inhibit PCE reduction in cell suspensions [36-38]. The constitutive PCE reductive dehalogenase mediates PCE reduction to DCE. It has been purified and characterized (Table 2) and the gene encoding the enzyme cloned and sequenced.

\subsection{Desulfuromonas chloroethenica}

This Gram-negative, sulfur-reducing bacterium utilizes pyruvate or acetate as the electron donor for the reduction of PCE or TCE to DCE [39]. It is doubtful whether the reductive dechlorination of 
Table 2

Properties of reductive dehalogenases

\begin{tabular}{|c|c|c|c|c|c|c|c|c|}
\hline Enzyme & $\begin{array}{l}\text { 3-Cl-benzoate } \\
\text { reductive } \\
\text { dehalogenase [49] }\end{array}$ & $\begin{array}{l}\text { Cl-OHPA } \\
\text { reductive } \\
\text { dehalogenase }^{\mathrm{a}}\end{array}$ & $\begin{array}{l}\text { Cl-OHPA } \\
\text { reductive } \\
\text { dehalogenase [50] }\end{array}$ & $\begin{array}{l}\text { PCE } \\
\text { reductive } \\
\text { dehalogenase [52] }\end{array}$ & $\begin{array}{l}\text { PCE } \\
\text { reductive } \\
\text { dehalogenase [54] }\end{array}$ & $\begin{array}{l}\text { PCE } \\
\text { reductive } \\
\text { dehalogenase [55] }\end{array}$ & $\begin{array}{l}\text { PCE } \\
\text { reductive } \\
\text { dehalogenase [61] }\end{array}$ & $\begin{array}{l}\text { TCE } \\
\text { reductive } \\
\text { dehalogenase [61] }\end{array}$ \\
\hline Organism & $\begin{array}{l}\text { Desulfomonile } \\
\text { tiedjei }\end{array}$ & $\begin{array}{l}\text { Desulfitobacterium } \\
\text { dehalogenans }\end{array}$ & $\begin{array}{l}\text { Desulfitobacterium } \\
\text { hafniense }\end{array}$ & $\begin{array}{l}\text { Desulfitobacterium } \\
\text { strain PCE-S }\end{array}$ & $\begin{array}{l}\text { Dehalobacter } \\
\text { restrictus }\end{array}$ & $\begin{array}{l}\text { Dehalospirillum } \\
\text { multivorans }\end{array}$ & $\begin{array}{l}\text { Dehalococcoides } \\
\text { ethenogenes }\end{array}$ & $\begin{array}{l}\text { Dehalococcoides } \\
\text { ethenogenes }\end{array}$ \\
\hline $\begin{array}{l}\text { Substrate } \\
\text { Localization }\end{array}$ & $\begin{array}{l}\text { 3-Cl-benzoate } \\
\text { membrane }\end{array}$ & $\begin{array}{l}\text { Cl-OHPA } \\
\text { membrane }\end{array}$ & $\begin{array}{l}\text { Cl-OHPA } \\
\text { membrane }\end{array}$ & $\begin{array}{l}\text { PCE, TCE } \\
\text { membrane }\end{array}$ & $\begin{array}{l}\text { PCE, TCE } \\
\text { membrane }\end{array}$ & $\begin{array}{l}\text { PCE, TCE } \\
\text { cytoplasm }^{\mathrm{b}}\end{array}$ & $\begin{array}{l}\text { PCE } \\
\text { membrane }\end{array}$ & $\begin{array}{l}\text { TCE, DCE, VC } \\
\text { membrane }\end{array}$ \\
\hline \multicolumn{9}{|c|}{$\begin{array}{l}\text { Apparent } \\
\text { molecular mass: }\end{array}$} \\
\hline Gel filtration $(\mathrm{kDa})$ & n.d. & n.d. & n.d. & 198 & $164 / 71^{\mathrm{c}}$ & 58 & n.d. & n.d. \\
\hline SDS-PAGE (kDa) & $64(\alpha) ; 37(\beta)$ & 48 & 47 & 65 & 60 & 57 & 51 & 61 \\
\hline Apparent $K_{\mathrm{m}}(\mu \mathrm{M})$ & n.d. & 20 (Cl-OHPA) & n.d. & 10 (PCE) & 20 (PCE) & 200 (PCE) & n.d. & n.d. \\
\hline $\begin{array}{l}\text { Specific activity in } \\
\text { cell extracts (nkat/mg) }\end{array}$ & 2.5 & 2.5 & 9.1 & 4 & 10 & 25 & 5 & 8 \\
\hline $\begin{array}{l}\text { Specific activity of the } \\
\text { purified enzyme } \\
\text { (nkat/mg) }\end{array}$ & 300 & 167 & 103 & 650 & 234 & 2640 & 350 & 200 \\
\hline $\begin{array}{l}\text { Cofactors } \\
\text { (mol/mol subunit) }\end{array}$ & $\begin{array}{l}\text { heme, } \\
\text { Fe/S: } \\
\text { n.d. }\end{array}$ & $\begin{array}{l}\text { corrinoid }^{\mathrm{d}} \\
\mathrm{Fe} / \mathrm{S}^{\mathrm{e}}\end{array}$ & $\begin{array}{l}1 \text { corrinoid, } \\
12 \mathrm{Fe}, 13 \mathrm{~S}\end{array}$ & $\begin{array}{l}1 \text { corrinoid, } \\
8 \mathrm{Fe}, 8 \mathrm{~S}\end{array}$ & $\begin{array}{l}1 \text { corrinoid, } \\
8 \mathrm{Fe}, 8 \mathrm{~S}\end{array}$ & $\begin{array}{l}1 \text { corrinoid, } \\
8 \mathrm{Fe}, 8 \mathrm{~S}\end{array}$ & $\begin{array}{l}\text { corrinoid }^{\mathrm{d}} \\
\text { Fe/S: n.d. }\end{array}$ & $\begin{array}{l}\text { corrinoid }^{\mathrm{d}} \\
\text { Fe/S: n.d. }\end{array}$ \\
\hline $\begin{array}{l}\text { Oxygen sensitivity } \\
t_{1 / 2}(\min )\end{array}$ & stable & $\approx 90$ & $\approx 100^{\mathrm{f}}$ & 50 & 280 & 120 & n.d. & n.d. \\
\hline
\end{tabular}

Cl-OHPA, 3-chloro-4-hydroxy-phenylacetate; n.d., not determined; PCE, tetrachloroethene; TCE, trichloroethene; DCE, cis-1,2-dichloroethene; VC, vinyl chloride.

${ }^{a}$ van de Pas, personal communication.

${ }^{\mathrm{b}}$ Catalytically active subunit.

${ }^{c}$ Dependent on the detergent present.

${ }^{\mathrm{d}}$ Indicated by light-reversible inhibition with alkyl halides.

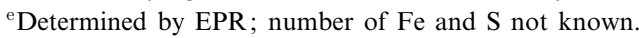

${ }^{\mathrm{f}}$ Determined in the membrane fraction. 
PCE is coupled to energy conservation [40]. It cannot be ruled out that acetate oxidation, rather than PCE reduction, is the energy yielding pathway, assuming that acetate oxidation occurs via a modified tricarboxylic acid cycle, including a succinyl-CoA:acetate CoA-transferase and an ATP citrate lyase as described for Desulfobacter postgatei [41]. The organism contains cytochrome $c$.

\subsection{Dehalococcoides ethenogenes}

This organism is a eubacterium without close affiliation to any known group [42]. It is the only anaerobe isolated so far which is able to completely dechlorinate PCE via TCE, DCE, and vinyl chloride (VC) to ethene with hydrogen as electron donor, indicating energy conservation via dehalorespiration. Alternative electron donors and acceptors tested were found not to be utilized. Two reductive dehalogenases, which have since been purified (Table 2), mediate the reduction of PCE to TCE and of TCE to ethene via DCE and VC.

\subsection{Enterobacter strain MS-1 and E. agglomerans}

These Gram-negative bacteria, which belong to the $\gamma$-subgroup of the Proteobacteria, are the only facultative anaerobes reported so far now to reductively dechlorinate PCE, thereby converting it to DCE. This occurs only under strictly anoxic conditions [43]. A variety of electron donors were utilized for PCE reduction. The coupling of energy conservation with reductive dehalogenation could not be demonstrated.

\subsection{DCE dechlorinating mixed cultures}

Several mixed cultures have been described which are able to completely dechlorinate PCE to ethene. The dichloroethene-utilizing organisms in these mixed cultures are obviously difficult to isolate and/ or cultivate. It should be noted that DCE reduction to ethene in such cultures was found to be inhibited by bromoethanesulfonate (BES) in the absence of methanogenesis. BES was formerly thought to be a specific inhibitor of methanogenesis. Thus, inhibition of reductive dechlorination by BES is not indicative of the involvement of methanogens [44].

\subsection{Reductive dechlorination in syntrophic associations}

Chlorinated compounds may also be reductively dechlorinated in defined or undefined syntrophic consortia. Experiments were performed with a defined consortium consisting of Desulfovibrio desulfuricans, producing hydrogen upon oxidation of ethanol to acetate in the absence of sulfate concentrations greater than $5 \mathrm{mM}$, Dehalospirillum multivorans as a $\mathrm{H}_{2}$ and PCE utilizing bacterium, and Methanobacterium formicicum as a bacterium competing for the use of the hydrogen. Under the experimental conditions imposed, the dechlorinating organism outcompeted the methanogen, demonstrating the high affinity of this organism for $\mathrm{H}_{2}$ [45]. Earlier studies on mixed cultures [46-48] led to the conclusion that at least some dechlorinators must have a higher affinity for $\mathrm{H}_{2}$ than methanogens.

A stable consortium consisting of Desulfomonile tiedjei, a benzoate-utilizing bacterium BZ-2, and a Methanospirillum species was found to convert 3-chlorobenzoate to acetate and methane [7]. In this consortium Desulfomonile tiedjei produced benzoate from 3-chlorobenzoate plus $\mathrm{H}_{2}$. Benzoate was converted to acetate, $\mathrm{H}_{2}$ and $\mathrm{CO}_{2}$ by the syntrophic organism BZ-2. The methanogen also utilized the hydrogen formed upon benzoate oxidation and provided vitamins for Desulfomonile tiedjei. In this consortium, none of the $\mathrm{H}_{2}$-consuming bacteria outcompeted any others.

\section{Biochemistry and molecular biology of reductive dehalogenases}

The reductive dehalogenases studied up until now have mediated the in vitro reduction of the chlorinated compounds with methyl viologen (MV; $E^{\circ \prime}=-446 \mathrm{mV} ; \varepsilon_{578}=9.7 \mathrm{mM}^{-1} \mathrm{~cm}^{-1}$ ) as an artificial electron donor according to the following equation:

$$
\begin{gathered}
\mathrm{R}-\mathrm{Cl}+2 \mathrm{MV}^{+} \text {(blue) }+\mathrm{H}^{+} \rightarrow \mathrm{R}-\mathrm{H}+ \\
2 \mathrm{MV}^{2+} \text { (colorless) }+\mathrm{Cl}^{-}
\end{gathered}
$$

This simple reaction allowed for the spectrophoto- 
metric recording of the reaction and was also essential for the purification of these enzymes. Due to the low redox potential of the reduced $\mathrm{MV}$, this reaction had to be measured in the absence of molecular oxygen. The characteristics of the reductive dehalogenases which have so far been purified are summarized in Table 2.

\subsection{3-Chlorobenzoate reductive dehalogenase of Desulfomonile tiedjei}

The first reductive dehalogenase reported to have been purified was the membrane-bound 3-chlorobenzoate converting enzyme from Desulfomonile tiedjei [49]. This oxygen-stable enzyme consists of two subunits with apparent molecular masses of 64 and $37 \mathrm{kDa}$, respectively. The purified protein exhibited UV-visible spectra, suggesting the presence of a heme cofactor for the protein; however, the cofactor content was not determined. The co-induction of the enzyme by a cytochrome $c$ of a negative redox potential indicates the involvement of this cytochrome in 3-chlorobenzoate respiration [20].

All other reductive dehalogenases appeared to contain a corrinoid as a cofactor. This was surprising since corrinoids had not previously been known to catalyze any reactions involving electron transfer.

\subsection{Ortho-chlorophenol reductive dehalogenases of Desulfitobacteria}

The reductive dehalogenases converting 3-chloro4-hydroxy-phenylacetate (Cl-OHPA) have recently been purified from Desulfitobacterium dehalogenans (van de Pas, personal communication) and Desulfitobacterium hafniense [50]. The membrane-bound enzymes consist of a single subunit with apparent molecular masses of 48 and $47 \mathrm{kDa}$, respectively. The enzyme of Desulfitobacterium dehalogenans, which also dehalogenated 2,3-dichlorophenol (van de Pas, personal communication), was light-reversibly inactivated by propyl iodide, indicating the presence of a corrinoid cofactor. The presence of a corrinoid was confirmed by preliminary EPR experiments that also revealed the presence of iron-sulfur clusters (van de Pas, personal communication). The enzyme of Desulfitobacterium hafniense contains one corrinoid and about $12 \mathrm{Fe}$ and 13 acid-labile sulfur per subunit [50].

An oxygen-stable 2,3-dichlorophenol-reducing enzyme system was found to be localized in the cytoplasmic membrane of Desulfitobacterium chlororespirans [51]. The reductive dehalogenase in crude membrane fractions was shown to be inhibited by sulfite, which also acted as an inhibitor for other reductive dehalogenases. Methyl viologen, rather than benzyl viologen, served as the artificial electron donor for the dechlorination reaction.

\subsection{Dehalogenases reducing chlorinated ethenes}

The PCE reductive dehalogenase of Desulfitobacterium strain PCE-S is membrane-associated [52]. This enzyme has been purified from cells grown with pyruvate and fumarate as energy sources, indicating its constitutive expression [52]. The enzyme, which mediates the reduction of PCE and TCE to DCE, consists of a single subunit with an apparent molecular mass of $65 \mathrm{kDa}$. It contains one corrinoid and around $8 \mathrm{Fe}$ and 8 acid-labile sulfur as cofactors. Chlorinated aromatic compounds like ClOHPA were not converted by the enzyme. The enzyme was found to be inhibited by cyanide and sulfite, an observation which indirectly indicated the involvement of a cob(III)alamin in the catalytic cycle of the dechlorination reaction [52,53]. Although the standard redox potentials $\left(E^{\circ \prime}\right)$ of the couples PCE/ TCE $(+580 \mathrm{mV})$ and TCE/DCE $(+540 \mathrm{mV})$ are very positive (see above), it was found that PCE reduction in vitro required electron donors with redox potentials $<-360 \mathrm{mV}$, indicating a reduction of cob(II)alamin to cob(I)alamin in the catalytic cycle of the reaction (enzyme-bound $\operatorname{cob}(\mathrm{II}) / \mathrm{cob}(\mathrm{I})$ alamins: $E^{\circ \prime}$ between -350 and $-600 \mathrm{mV}$ ).

A PCE reductive dehalogenase with properties similar to those of the strain PCE-S enzyme has been purified from Dehalobacter restrictus [54]. This enzyme, which catalyzes the reductive dechlorination of PCE to DCE, appears to be an integral membrane protein. The single subunit $(60 \mathrm{kDa})$ contains a corrinoid with a standard redox potential of $-350 \mathrm{mV}$, as determined by EPR spectroscopy. In addition, the EPR studies performed showed that the cobalt is not coordinated by either a base or a histidine, and that it must hence be present in the base-off and his-off 
form. In addition, the presence of $2 \mathrm{Fe}_{4} \mathrm{~S}_{4}$ clusters with redox potentials around $-480 \mathrm{mV}$, which are probably involved in the electron transfer, was reported. The amino acid sequence of the $\mathrm{N}$-terminus of the enzyme [52] showed a high degree of similarity to that of the PCE reductive dehalogenase of Desulfitobacterium strain PCE-S (19 out of 20 amino acids were identical; Schumacher and Holliger, unpublished results).

The PCE reductive dehalogenase of Dehalospirillum multivorans, which is also known to reduce PCE to DCE, was recovered in the soluble fraction and was the only reductive dehalogenase purified in the absence of detergents [55]. This was surprising, since this enzyme is involved in a respiratory process and would thus be expected to be membrane-associated. This enzyme was the first PCE reducing dehalogenase purified and characterized. The soluble protein fraction consists of a single subunit with an apparent molecular mass of $58 \mathrm{kDa}$. The enzyme contains one corrinoid and about $8 \mathrm{Fe}$ and 8 acid-labile sulfur per subunit. The requirement for a low potential electron donor $\left(E^{\circ \prime}<-360 \mathrm{mV}\right)$ as well as this enzyme's light-reversible inactivation by alkyl halides, provided the first indication of the involvement of a corrinoid cofactor in reductive dechlorination. Cyanide and sulfite were found to inhibit enzyme activity $[53,55]$, while ammonium ions were found to stimulate this activity. This effect has yet to be explained, and has so far only been observed for this specific PCE reductive dehalogenase.

The gene coding for the enzyme of Dehalospirillum multivorans was cloned in Escherichia coli and subsequently sequenced [56]. An operon was found, containing two open reading frames (ORFs), one of which $(p c e A)$ encoded the soluble PCE reductive dehalogenase. Downstream of pceA a second ORF, pceB (222 bp), was found, which coded for a hydrophobic protein, PceB $(8.4 \mathrm{kDa})$, containing two transmembrane helices. This protein did not contain either histidine or cysteine, indicating the absence of a bound $\mathrm{Fe}-\mathrm{S}$ cluster or a heme prosthetic group. It was suggested that this protein served as a 'membrane anchor' for the soluble, catalytic subunit of the PCE reductive dehalogenase PceA. This role for PceB would be in accordance with the function of PceA in respiratory processes.
The ORF pceA was comprised of $1503 \mathrm{bp}$ and contained the binding motifs for two iron-sulfur clusters. These binding motifs corresponded to the typical consensus sequence for the binding of two $\mathrm{Fe}_{4} \mathrm{~S}_{4}$ clusters [57], with the exception that the first cysteine of the second cluster required for the binding of one of the $\mathrm{Fe}$ atoms was replaced by glycine. As a result, it cannot be excluded that one of the iron-sulfur clusters may contain $3 \mathrm{Fe}$ rather than 4. The typical $\mathrm{B}_{12}$ binding motif (DXHXXG) [58] was not found. At the $5^{\prime}$ terminus of pceA, a signal sequence containing the consensus sequence RRXFXK followed by a hydrophobic stretch [59], was detected. This type of leader sequence is usually found in periplasmic proteins containing redoxactive cofactors, where it is responsible for the excretion of the native holoenzyme. Aside from the PCE reductive dehalogenase of Dehalospirillum multivorans, only one other cytoplasmic protein has been reported to contain this leader sequence, namely the dimethylsulfoxide reductase of Escherichia coli. This latter protein contains a small hydrophobic subunit, the role of which is to prevent the enzyme from being exported into the periplasm [60]. It is feasible that the small hydrophobic 'subunit', PceB, of the reductive PCE dehalogenase of Dehalospirillum multivorans fulfils a similar role in this enzyme.

With the exception of the leader sequence and the consensus sequences for the binding of the Fe/S clusters, no similarities between the pce $A$ and $p c e B$ and any other known proteins in the gene databases were found. In addition, the N-terminus of the processed, as well as of the unprocessed protein did not exhibit any similarities to the N-termini of the PCE reductive dehalogenases of Dehalobacter restrictus and strain PCE-S.

Two membrane-bound reductive dehalogenases have been purified via gel electrophoresis from a mixed enrichment culture containing Dehalococcoides ethenogenes [61]. The PCE reductive dehalogenase $(51 \mathrm{kDa})$ mediates PCE reduction to TCE, and the TCE reductive dehalogenase $(61 \mathrm{kDa})$ TCE reduction to ethene. Both enzymes probably contain a corrinoid, as indicated by light-reversible inhibition by alkyl halides. Cyanide and sulfite inhibit the activity of both enzymes. 


\section{Reaction mechanism of corrinoid-dependent reductive dehalogenases}

Based on the finding that low-potential electron donors $(<-360 \mathrm{mV})$ are required for corrinoid-dependent reductive dechlorination, it can be concluded that an enzyme-bound cob(I)alamin is involved in the reaction. Two reaction mechanisms have been proposed for the reductive dechlorination of PCE: (1) the addition of cob(I)alamin to one of the carbons with subsequent $\beta$-elimination of the chlorine substituent [9]; and (2) a one-electron transfer from the cob(I)alamin to PCE followed by an elimination of a chloride anion, yielding a trichloroethenyl radical that combines with a $\mathrm{H}$-radical to yield TCE [62]. The first mechanism is based purely on theoretical considerations, but there is experimental evidence for the second [54,62-64]. The PCE reductive dehalogenases of Dehalospirillum multivorans and of Desulfitobacterium strain PCE-S are also able to enzymatically dechlorinate chlorinated propenes [63,64]. Trans-1,3-dichloropropene is dechlorinated to 1-chloropropene. The fact that elimination of the chlorine substituent occurs from the $s p^{3}$ hybridized carbon rather than from the $s p^{2}$ hybridized C-1 clearly argues against an addition at $\mathrm{C}$-1/elimination at $\mathrm{C}-2$ reaction, since this mechanism would yield vinyl chloride plus methyl chloride as the reaction products. The dechlorination at $\mathrm{C}-3$ is also contradictory to an addition/elimination at $\mathrm{C}-2$, which would result in the formation of 3-chloropropene. From these findings it may be deduced that the dechlorination at C-3 must be due either to a radical (= one-electron transfer) mechanism or to a substitution reaction.

Indirect evidence for a one-electron transfer is available from EPR data of the purified PCE reductive dehalogenase of Dehalobacter restrictus, despite the fact that a radical signal indicating the formation of a radical intermediate was not observed [54]. Further studies will be required to elucidate the mechanism of this unusual reaction. A tentative scheme for a radical mechanism possibly involved in reductive dechlorination is outlined in Fig. 3. From all experimental data available, it is obvious that the cobalamin undergoes a change in its redox state during the catalytic cycle of the reaction. Hence, reductive dechlorination represents a new type of corrinoid-dependent reaction.

To date, only a small amount of information is available about the reductive dehalogenases which convert halogenated aromatic compounds as substrates. The finding that at least some of the reductive dehalogenases dechlorinating aryl halides also are corrinoid-dependent indicates that the presence of a corrinoid as a prosthetic group is a common

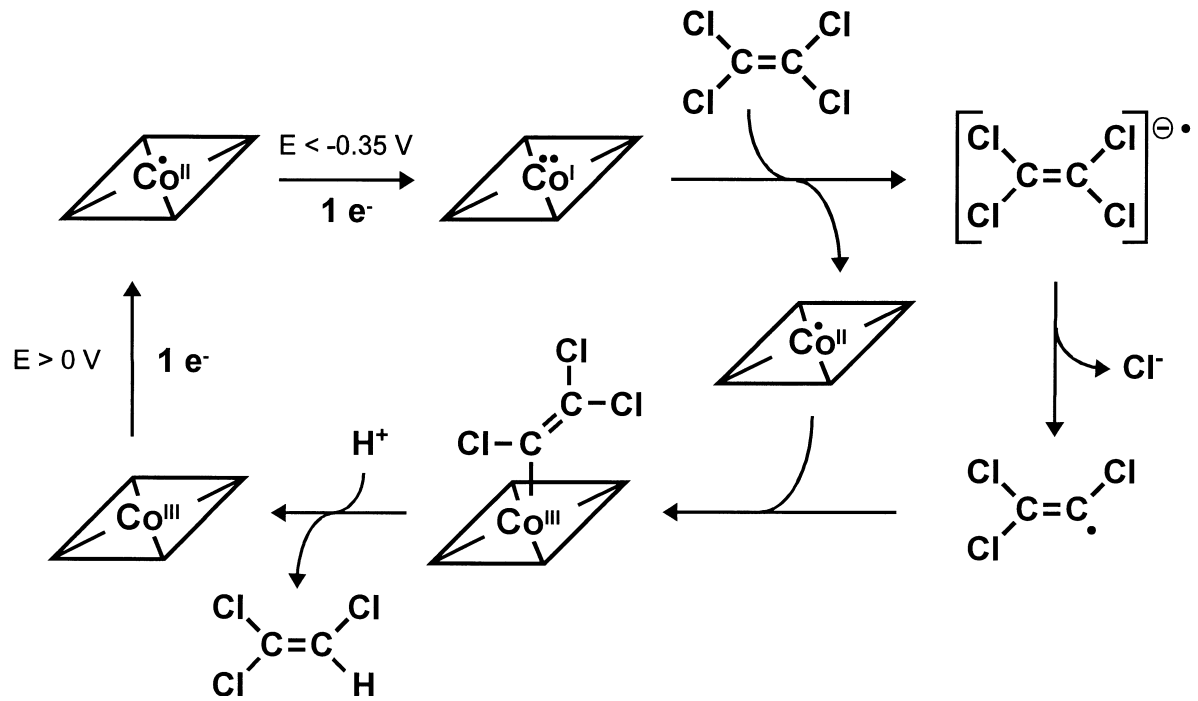

Fig. 3. Tentative scheme of the reductive dechlorination reaction mechanism involving a one-electron transfer (radical mechanism). $\mathrm{Co}^{\mathrm{I}-\mathrm{III}}$ within the rhombus represents the corrinoid with cobalt in the respective oxidation state. 
feature of reductive dehalogenases. Aryl halides are also abiotically converted by cobalamins [3]. So far, nothing is known about the mechanism of 3-chlorobenzoate dechlorination mediated by the heme-containing 3-chlorobenzoate reductive dehalogenase. Although hemes have been reported to mediate the abiotic reductive dechlorination of alkyl halides [3], heme-dependent, enzyme-mediated aryl halide dechlorination of aromatic compounds must also be considered as a new type of biochemical reaction.

\section{Energy conservation via dehalorespiration}

The coupling of hydrogen and formate oxidation to reductive dechlorination of chlorinated compounds implies energy conservation via electron transport phosphorylation. The first dissimilatory dechlorinating bacterium, Desulfomonile tiedjei, was isolated and shown to utilize pyruvate as an electron donor; respiratory growth was not unambiguously proven [13]. After extensive characterization and testing of different media, Desulfomonile tiedjei was successfully cultivated with hydrogen and formate as electron donors, thus providing the first evidence for growth via dehalorespiration [16,65]. Experiments with uncouplers, protonophores, and oxidant pulses in cell suspensions of Desulfomonile tiedjei further indicated chemiosmotic coupling of dechlorination and ATP synthesis [17]. Many of the bacteria listed in Table 1 utilize hydrogen and formate as electron donors, indicating the dissimilatory character of the catalyzed dechlorination reaction.

Electron transfer phosphorylation requires an association between the proteins involved and the cytoplasmic membrane. This was the case for the majority of the reductive dehalogenases described so far, with the exception of the PCE reductive dehalogenase of Dehalospirillum multivorans, which was always recovered in the soluble fraction (Table 2). It is thought, however, that this enzyme may well be anchored to the membrane by a hydrophobic protein $\mathrm{PceB}$, for which the gene $p c e B$ has been located in the same operon as the gene pce $A$ that encoded the soluble PCE reductive dehalogenase [56]. The localization and arrangement of the two major enzymes involved in the hydrogen-dependent dehalorespiration, the hydrogenase and the reductive dehaloge- nase, has been investigated for three PCE-dechlorinating bacteria $[6,34,38,53]$. In all cases, the hydrogenase was membrane-associated and faced the outside of the cytoplasmic membrane. The PCE reductive dehalogenases were all found to face the inside of the cytoplasmic membrane.

Based on this arrangement of the enzymes involved, and considerations of the presence of menaquinone and cytochrome $b$, a tentative model for the respiration can be proposed (Fig. 4). This model is very similar to the respiratory chain proposed for fumarate respiration in Wolinella succinogenes [66]. In Dehalobacter restrictus, it was found that cytochrome $b$ can be reduced by the hydrogenase (Schu-
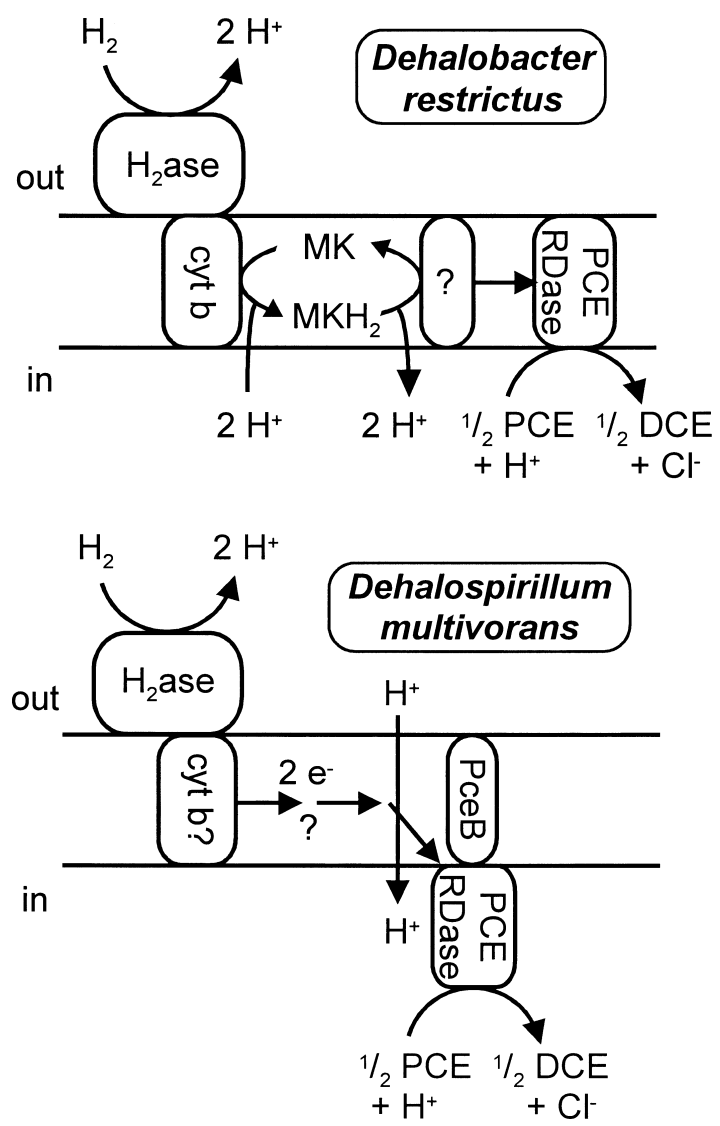

Fig. 4. Tentative scheme of dehalorespiration in Dehalobacter restrictus and Dehalospirillum multivorans. $\mathrm{MK}\left(\mathrm{H}_{2}\right)$, menaquinone in the oxidized or reduced state; cyt $\mathrm{b}$, cytochrome $b$; PCE RDase, PCE reductive dehalogenase; PceB, membrane anchor protein. 
macher and Holliger, unpublished). Redox difference spectra of membrane fractions, and experiments with the menaquinone analog 2,3-dimethyl-1,4-naphthoquinone (DMN) and the inhibitor 2-n-heptyl-4-hydroxyquinoline $N$-oxide provided evidence for the involvement of menaquinone in the electron transfer [34]. The involvement of a further component in the transfer of electrons from menaquinone to the PCE reductive dehalogenase is proposed based on experiments with reduced DMN. $\mathrm{DMNH}_{2}$ was observed to act as an electron donor for the PCE reductive dehalogenase in membrane fractions, but not in membrane extracts and not for the purified enzyme (Schumacher and Holliger, unpublished). This indicated that the respiration chain had to be intact and that menaquinone was therefore not the direct electron donor for the PCE reductive dehalogenase.

Without the involvement of a proton pump during the transfer of the electrons from the hydrogenase to the reductive dehalogenase, a proton motive force with a $\mathrm{H}^{+} / \mathrm{e}^{-}$ratio of 1.0 can be established. Oxidant pulse experiments with cell suspensions of Dehalobacter restrictus generated an extrapolated $\mathrm{H}^{+} / \mathrm{e}^{-}$ ratio of $1.25 \pm 0.2$, indicating that a proton pump is involved [34]. Menaquinone that could possibly function as proton translocating coenzyme during electron transfer was shown to take up and release the protons on the cytoplasmic side of the membrane during the redox reaction [34]. Hence, menaquinone does not function as a proton translocating compound in Dehalobacter restrictus. For Dehalospirillum multivorans, an involvement of menaquinone in electron transfer is doubtful [38].

The free energy $\left(\Delta G^{\circ \prime}\right)$ available from PCE dechlorination to DCE with hydrogen as the electron donor is $189 \mathrm{~kJ}$ per $\mathrm{mol} \mathrm{H}_{2}$. This amount of energy could theoretically yield approximately 2.5 ATP, assuming an energy requirement $\left(\Delta G^{\prime}\right)$ of $70 \mathrm{~kJ}$ per mol for the formation of 1 ATP from 1 ADP and $1 \mathrm{P}_{\mathrm{i}}$ [67]. The proposed respiratory chain generates a proton gradient of $2 \mathrm{H}^{+}$per mol $\mathrm{H}_{2}$, which corresponds to two-thirds of an ATP, taking into account that three protons cross the membrane per ATP formed [67]. The low cell yields found for different PCE dechlorinating bacteria $[32,35,42]$ indicate that not even 1 mol ATP is gained per chloride removed, which fits in nicely with the proposed respiration mechanism. In addition, evidence of a reversed elec- tron transport during dechlorination, which would consume part of the proton gradient formed, was obtained for Dehalospirillum multivorans [38]. This could explain the low ATP and biomass yields. However, no indications for a reversed electron transport have been found in Dehalobacter restrictus, as dechlorination still occurred in the presence of the protonophore carbonylcyanide $m$-chlorophenylhydrazone (CCCP) [34].

\section{Conclusions and outlook}

In the past decades, the chemical industry has developed a large variety of different chlorinated compounds to be used as intermediates for chemical synthesis, as cooling agents, solvents, pesticides, and many other applications. These chlorinated compounds can be reductively dechlorinated by anaerobic bacteria. The diversity of reductively dechlorinating bacteria is large, almost equaling the diversity of chlorinated compounds synthesized. However, many new genera and species of dechlorinating bacteria remain undiscovered. The dechlorinating organisms known at present belong, phylogenetically, to different groups of bacteria and range in their physiology from facultative anaerobes, nitrate, iron, and sulfoxy anion reducers, fermentative bacteria, and methanogens to strict reducers of chlorinated compounds. Some, such as acetogens and methanogens, reductively dechlorinate the chlorinated compounds in a co-metabolic reaction, while others utilize the chlorinated compounds as electron acceptors in their energy metabolism. For some of the latter organisms, it has been unambiguously proven that they dechlorinate the chlorinated compound in a process known as dehalorespiration. Dehalorespiration has best been characterized with PCE as the electron acceptor. Rather simple respiratory chains seem to be involved, which use the free energy that could be gained from the exergonic dechlorination reaction quite inefficiently. All of the reductive dehalogenases of PCE as well as aromatic compounds studied so far are membrane-associated enzymes, most of which contain a corrinoid, and possibly iron-sulfur clusters, as cofactors. The catalysis of dechlorination reactions that involves electron transfer is a new type of corrinoid-dependent reaction, but can also be cat- 
alyzed by reductases not containing a corrinoid cofactor. Although there is some experimental evidence in support of a single-electron transfer in the dechlorination of PCE, additional research is required to fully understand the reaction mechanism. So far, nothing is known about the respiratory chain and reaction mechanisms involved in the dehalogenation of aryl halides. The recent advances in investigating dissimilatory dehalogenation reactions have opened up a field that is of great interest and importance for fundamental as well as applied research. The big challenge now is to transfer the knowledge gained on the bacteria and biochemistry involved to applied situations, in order to realize the goal of being able to remediate polluted sites.

\section{Acknowledgments}

This work was supported by grants from the Deutsche Forschungsgemeinschaft, the BMBFT, and the Fonds der Chemischen Industrie to G.D. and by a grant from the Swiss National Science Foundation to C.H.

\section{References}

[1] El Fantroussi, S., Naveau, H. and Agathos, S.N. (1998) Anaerobic dechlorinating bacteria. Biotechnol. Prog. 14, 167-188.

[2] Fetzner, S. and Lingens, F. (1994) Bacterial dehalogenases: biochemistry, genetics, and biotechnological applications. Microbiol. Rev. 58, 641-685.

[3] Gantzer, C.J. and Wackett, L.P. (1991) Reductive dechlorination catalyzed by bacterial transition-metal coenzymes. Environ. Sci. Technol. 25, 715-722.

[4] Holliger, C. (1995) The anaerobic microbiology and biotreatment of chlorinated ethenes. Curr. Opin. Biotechnol. 6, 347351.

[5] Holliger, C., Gaspard, S., Glod, G., Heijman, C., Schumacher, W., Schwarzenbach, R.P. and Vazquez, F. (1997) Contaminated environments in the subsurface and bioremediation: organic contaminants. FEMS Microbiol. Rev. 20, 517-523.

[6] Holliger, C. and Schumacher, W. (1994) Reductive dehalogenation as a respiratory process. Antonie van Leeuwenhoek 66, 239-246.

[7] Mohn, W.W. and Tiedje, J.M. (1992) Microbial reductive dehalogenation. Microbiol. Rev. 56, 482-507.

[8] Vogel, T.M., Criddle, C.S. and McCarty, P.L. (1987) Transformation of halogenated aliphatic compounds. Environ. Sci. Technol. 21, 722-736.
[9] Wohlfarth, G. and Diekert, G. (1997) Anaerobic dehalogenases. Curr. Opin. Biotechnol. 8, 290-295.

[10] Miyauchi, K., Suh, S.K., Nagata, Y. and Takagi, M. (1998) Cloning and sequencing of a 2,5-dichlorohydroquinone reductive dehalogenase gene whose product is involved in degradation of gamma-hexachlorocyclohexane by Sphingomonas paucimobilis. J. Bacteriol. 180, 1354-1359.

[11] Vollmer, M.D., Stadler-Fritzsche, K. and Schlömann, M. (1993) Conversion of 2-chloromaleylacetate in Alcaligenes eutrophus JMP134. Arch. Microbiol. 159, 182-188.

[12] Dolfing, J. and Harrison, B.K. (1992) Gibbs free energy of formation of halogenated aromatic compounds and their potential role as electron acceptors in anaerobic environments. Environ. Sci. Technol. 26, 2213-2218.

[13] Shelton, D.R. and Tiedje, J.M. (1984) Isolation and partial characterization of bacteria in an anaerobic consortium that mineralizes 3-chlorobenzoic acid. Appl. Environ. Microbiol. 48, 840-848.

[14] DeWeerd, K.A., Mandelco, L., Tanner, R.S., Woese, C.R. and Suflita, J.M. (1991) Desulfomonile tiedjei gen. nov. and sp. nov., a novel anaerobic, dehalogenating, sulfate-reducing bacterium. Arch. Microbiol. 154, 23-30.

[15] DeWeerd, K.A., Concannon, F. and Suflita, J.M. (1991) Relationship between hydrogen consumption, dehalogenation, and the reduction of sulfur oxyanions by Desulfomonile tiedjei. Appl. Environ. Microbiol. 57, 1929-1934.

[16] Dolfing, J. (1990) Reductive dechlorination of 3-chlorobenzoate is coupled to ATP production and growth in an anaerobic bacterium, strain DCB-1. Arch. Microbiol. 153, 264 266.

[17] Mohn, W.W. and Tiedje, J.M. (1991) Evidence for chemiosmotic coupling of reductive dechlorination and ATP synthesis in Desulfomonile tiedjei. Arch. Microbiol. 157, 1-6.

[18] Cole, J.R., Fathepure, B.Z. and Tiedje, J.M. (1995) Tetrachloroethene and 3-chlorobenzoate dechlorination activities are co-induced in Desulfomonile tiedjei DCB-1. Biodegradation $6,167-172$.

[19] Townsend, G.T. and Suflita, J.M. (1996) Characterization of chloroethylene dehalogenation by cell extracts of Desulfomonile tiedjei and its relationship to chlorobenzoate dehalogenation. Appl. Environ. Microbiol. 62, 2850-2853.

[20] Louie, T.M., Ni, S., Xun, L. and Mohn, W.W. (1997) Purification, characterization and gene sequence analysis of a novel cytochrome c co-induced with reductive dechlorination activity in Desulfomonile tiedjei DCB-1. Arch. Microbiol. 168, 520527.

[21] Townsend, G.T. and Suflita, J.M. (1997) Influence of sulfur oxyanions on reductive dehalogenation activities in Desulfomonile tiedjei. Appl. Environ. Microbiol. 63, 3594-3599.

[22] Cole, J.R., Cascarelli, A.L., Mohn, W.W. and Tiedje, J.M. (1994) Isolation and characterization of a novel bacterium growing via reductive dehalogenation of 2-chlorophenol. Appl. Environ. Microbiol. 60, 3536-3542.

[23] Granzow, S. (1998) Isolierung und Charakterisierung eines neuen Tetrachlorethen dechlorierenden strikt anaeroben Bakteriums, Desulfitobacterium frappieri Stamm PCE-S. Ph.D. Thesis, Universität Stuttgart, Stuttgart, Germany. 
[24] Christiansen, N. and Ahring, B.K. (1996) Desulfitobacterium hafniense sp. nov., an anaerobic, reductively dechlorinating bacterium. Int. J. Syst. Bacteriol. 46, 442-448.

[25] Gerritse, J., Renard, V., Gomes, T.M.P., Lawson, P.A., Collins, M.D. and Gottschal, J.C. (1996) Desulfitobacterium sp. strain PCE1, an anaerobic bacterium that can grow by reductive dechlorination of tetrachloroethene or ortho-chlorinated phenols. Arch. Microbiol. 165, 132-140.

[26] Sanford, R.A., Cole, J.R., Löffler, F.E. and Tiedje, J.M. (1996) Characterization of Desulfitobacterium chlororespirans sp. nov., which grows by coupling the oxidation of lactate to the reductive dechlorination of 3-chloro-4-hydroxybenzoate. Appl. Environ. Microbiol. 62, 3800-3808.

[27] Bouchard, B., Beaudet, R., Villemur, R., McSween, G., Lepine, F. and Bisaillon, J.G. (1996) Isolation and characterization of Desulfitobacterium frappieri sp. nov., an anaerobic bacterium which reductively dechlorinates pentachlorophenol to 3-chlorophenol. Int. J. Syst. Bacteriol. 46, 1010-1015.

[28] Utkin, I., Woese, C. and Wiegel, J. (1994) Isolation and characterization of Desulfitobacterium dehalogenans gen. nov., sp. nov., an anaerobic bacterium which reductively dechlorinates chlorophenolic compounds. Int. J. Syst. Bacteriol. 44, 612619 .

[29] Utkin, I., Dalton, D.D. and Wiegel, J. (1995) Specificity of reductive dehalogenation of substituted ortho-chlorophenols by Desulfitobacterium dehalogenans JW/IU-DC1. Appl. Environ. Microbiol. 61, 346-351.

[30] Mackiewicz, M. and Wiegel, J. (1998) Comparison of energy and growth yields for Desulfitobacterium dehalogenans during utilization of chlorophenol and various traditional electron acceptors. Appl. Environ. Microbiol. 64, 352-355.

[31] Holliger, C., Schraa, G., Stams, A.J.M. and Zehnder, A.J.B. (1993) A highly purified enrichment culture couples the reductive dechlorination of tetrachloroethene to growth. Appl. Environ. Microbiol. 59, 2991-2997.

[32] Holliger, C., Hahn, D., Harmsen, H., Ludwig, W., Schumacher, W., Tindall, B., Vazquez, F., Weiss, N. and Zehnder, A.J.B. (1998) Dehalobacter restrictus gen. nov. and sp. nov., a strictly anaerobic bacterium that reductively dechlorinates tetra- and trichloroethene in an anaerobic respiration. Arch. Microbiol. 169, 313-321.

[33] Wild, A., Hermann, R. and Leisinger, T. (1996) Isolation of an anaerobic bacterium which reductively dechlorinates tetrachloroethene and trichloroethene. Biodegradation 7, 507511.

[34] Schumacher, W. and Holliger, C. (1996) The proton electron ratio of the menaquinone-dependent electron transport from dihydrogen to tetrachloroethene in 'Dehalobacter restrictus'. J. Bacteriol. 178, 2328-2333.

[35] Scholz-Muramatsu, H., Neumann, A., Meßmer, M., Moore, E. and Diekert, G. (1995) Isolation and characterization of Dehalospirillum multivorans gen. nov. sp. nov., a tetrachloroethene-utilizing, strictly anaerobic bacterium. Arch. Microbiol. $163,48-56$.

[36] Neumann, A., Scholz-Muramatsu, H. and Diekert, G. (1994) Tetrachloroethene metabolism of Dehalospirillum multivorans. Arch. Microbiol. 162, 295-301.
[37] Neumann, A., Wohlfarth, G. and Diekert, G. (1995) Properties of the tetrachloroethene and trichloroethene dehalogenase of Dehalospirillum multivorans. Arch. Microbiol. 163, 276281.

[38] Miller, E., Wohlfarth, G. and Diekert, G. (1997) Studies on tetrachloroethene respiration in Dehalospirillum multivorans. Arch. Microbiol. 166, 379-387.

[39] Krumholz, L.R. (1997) Desulfuromonas chloroethenica sp. nov. uses tetrachloroethylene and trichloroethylene as electron acceptors. Int. J. Syst. Bacteriol. 47, 1262-1263.

[40] Krumholz, L.R., Sharp, R. and Fishbain, S.S. (1996) A freshwater anaerobe coupling acetate oxidation to tetrachloroethylene dehalogenation. Appl. Environ. Microbiol. 62, 41084113.

[41] Thauer, R.K., Möller-Zinkhan, D. and Spormann, A.M. (1989) Biochemistry of acetate catabolism in anaerobic chemotrophic bacteria. Annu. Rev. Microbiol. 43, 43-67.

[42] Maymó-Gatell, X., Chien, Y.-T., Gossett, J.M. and Zinder, S.H. (1997) Isolation of a bacterium that reductively dechlorinates tetrachloroethene to ethene. Science 226, 1568-1571.

[43] Sharma, P.K. and McCarty, P.L. (1996) Isolation and characterization of a facultatively aerobic bacterium that reductively dehalogenates tetrachloroethylene to cis-1,2-dichloroethylene. Appl. Environ. Microbiol. 62, 761-765.

[44] Löffler, F.E., Ritalahti, K.M. and Tiedje, J.M. (1997) Dechlorination of chloroethenes is inhibited by 2-bromoethanesulfonate in the absence of methanogens. Appl. Environ. Microbiol. 63, 4982-4985.

[45] Eisenbeis, M. (1998) Kinetische Untersuchungen zur reduktiven Dechlorierung von Tetrachlorethen in Dehalospirillum multivorans in Zellsuspensionen und im Biofilm. Ph.D. Thesis, Universität Stuttgart, Stuttgart, Germany.

[46] Smatlak, C.R., James M. Gossett, J.M. and Zinder, S.H. (1996) Comparative kinetics of hydrogen utilization for reductive dechlorination of tetrachloroethene and methanogenesis in an anaerobic enrichment culture. Environ. Sci. Technol. 30, $2850-2858$.

[47] Fennell, D.E., Gossett, J.M. and Zinder, S.H. (1997) Comparison of butyric acid, ethanol, lactic acid, and propionic acid as hydrogen donors for the reductive dechlorination of tetrachloroethene. Environ. Sci. Technol. 31, 918-926.

[48] Ballapragada, B.S., Stensel, H.D., Puhakka, J.A. and Ferguson, J.F. (1997) Effect of hydrogen on reductive dechlorination of chlorinated ethenes. Environ. Sci. Technol. 31, 17281734.

[49] Ni, S., Fredrickson, J.K. and Xun, L. (1995) Purification and characterization of a novel 3-chlorobenzoate-reductive dehalogenase from the cytoplasmic membrane of Desulfomonile tiedjei DCB-1. J. Bacteriol. 177, 5135-5139.

[50] Christiansen, N., Ahring, B.K., Wohlfarth, G. and Diekert, G. (1998) Purification and characterization of the 3-chloro-4hydroxy-phenylacetate reductive dehalogenase of Desulfitobacterium hafniense. FEBS Lett. 436, 159-162.

[51] Löffler, F.E., Sanford, R.A. and Tiedje, J.M. (1996) Initial characterization of a reductive dehalogenase from Desulfitobacterium chlororespirans Co23. Appl. Environ. Microbiol. 62, 3809-3813. 
[52] Miller, E., Wohlfarth, G. and Diekert, G. (1998) Purification and characterization of the tetrachloroethene reductive dehalogenase of strain PCE-S. Arch. Microbiol. 169, 497-502.

[53] Miller, E., Wohlfarth, G. and Diekert, G. (1997) Comparative studies on tetrachloroethene reductive dechlorination mediated by Desulfitobacterium sp. strain PCE-S. Arch. Microbiol. $168,513-519$.

[54] Schumacher, W., Holliger, C., Zehnder, A.J.B. and Hagen, W.R. (1997) Redox chemistry of cobalamin and iron-sulfur cofactors in the tetrachloroethene reductase of Dehalobacter restrictus. FEBS Lett. 409, 421-425.

[55] Neumann, A., Wohlfarth, G. and Diekert, G. (1996) Purification and characterization of tetrachloroethene reductive dehalogenase from Dehalospirillum multivorans. J. Biol. Chem. 271, 16515-16519.

[56] Neumann, A., Wohlfarth, G. and Diekert, G. (1998) Tetrachloroethene dehalogenase from Dehalospirillum multivorans: cloning, sequencing of the encoding genes, and expression of the pceA gene in Escherichia coli. J. Bacteriol. 180, 4140-4145.

[57] Bruschi, M. and Guerlesquin, F. (1988) Structure, function and evolution of bacterial ferredoxins. FEMS Microbiol. Rev. 54, 155-176.

[58] Marsh, E.N.G. and Holloway, D.E. (1992) Cloning and sequencing of glutamate mutase component S from Clostridium tetanomorphum. FEBS Lett. 310, 167-170.

[59] Berks, B.C. (1996) A common export pathway for proteins binding complex redox cofactors? Mol. Microbiol. 22, 393404.
[60] Weiner, J.H., Bilous, P.T., Shaw, G.M., Lubitz, S.P., Frost, L., Thomas, G.H., Cole, J.A. and Turner, R.J. (1998) A novel and ubiquitous system for membrane targeting and secretion of cofactor-containing proteins. Cell 93, 93-101.

[61] Magnuson, J.K., Stern, R.V., Gossett, J.M., Zinder, S.H. and Burris, D.R. (1998) Reductive dechlorination of tetrachloroethene to ethene by a two-component enzyme pathway. Appl. Environ. Microbiol. 64, 1270-1275.

[62] Glod, G., Angst, W., Holliger, C. and Schwarzenbach, R.P. (1997) Corrinoid-mediated reduction of tetrachloroethene, trichloroethene, and trifluoroethene in homogenous aqueous solution: reaction kinetics and reaction mechanisms. Environ. Sci. Technol. 31, 253-260.

[63] Miller, E. (1998) Comparative studies on tetrachloroethene reductive dechlorination in two anaerobic bacteria. Ph.D. Thesis, Universität Stuttgart, Stuttgart, Germany.

[64] Trescher, T. (1998) Dechlorierung von Chlorpropenen durch die Tetrachlorethen-Dehalogenase aus Dehalospirillum multivorans. Diploma Thesis, Universität Stuttgart, Stuttgart, Germany.

[65] Mohn, W.W. and Tiedje, J.M. (1990) Strain DCB-1 conserves energy for growth from reductive dechlorination coupled to formate oxidation. Arch. Microbiol. 153, 267-271.

[66] Kröger, A., Geisler, V., Lemma, E., Theis, F. and Lenger, R. (1992) Bacterial fumarate respiration. Arch. Microbiol. 158, 311-314.

[67] Schink, B. and Friedrich, M. (1994) Energetics of syntrophic fatty acid oxidation. FEMS Microbiol. Rev. 15, 85-94. 